\title{
Pengaruh Penambahan Varian Ubi Jalar terhadap Sifat Organoleptik Es Krim
}

\author{
Anisa Nur Baitirahman ${ }^{\mathrm{a}, 1, *}$, Nurul Putrie Utami ${ }^{\mathrm{b}, 2}$ \\ a Bisnis Jasa Makanan, Universitas Ahmad Dahlan, Jalan Pramuka No. 42, Yogyakarta 55161, Indonesia \\ ${ }^{\mathrm{b}}$ Bisnis Jasa Makanan, Universitas Ahmad Dahlan, Jalan Pramuka No. 42, Yogyakarta 55161, Indonesia \\ ${ }^{1}$ anisanurbaitirahman@gmail.com*; ${ }^{2}$ nurul.putrie@ culinary.uad.ac.id \\ * penulis korespondensi
}

\begin{abstract}
Ice cream is a frozen food processed product that is commonly consumed as a snack (dessert) with the main ingredients: fat, non-fat dry ingredients, sweeteners, emulsifiers and stabilizers. This study aims to determine the effect of adding sweet potatoes to the organoleptic properties of ice cream. The treatment carried out in this study was the comparison of the administration of sweet potatoes of different colors with the following formula: $B 1=$ without addition (0\%); $B 2=$ addition of $7.5 \%$ purple sweet potato; $B 3=$ the addition of $15 \%$ purple yam; $B 4=$ addition of $22.5 \%$ purple sweet potato; $B 5=$ addition of $22.5 \%$ yellow sweet potato; and $B 6=$ addition of $22.5 \%$ white sweet potato. This study used a completely randomized design which was assessed by 22 semi-trained panelists as a test. The results of this study indicate that administration of sweet potato influences organoleptic properties in the form of varying colors, aromas, flavors, and textures. The softest texture is found in products without a mixture of purple yam (B1). The best texture with sweet potato mixture, soft and slightly fibrous, is found in purple sweet potato mixture with low sweet potato with formulation of $7.5 \%$ (B2) and 15\% (B3).
\end{abstract}

Keywords: ice cream, organoleptic properties, sweet potato

\begin{abstract}
ABSTRAK
Es krim merupakan produk olahan pangan beku yang biasa dikonsumsi sebagai makanan selingan (dessert) dengan bahan utama dalam pembuatannya seperti lemak, bahan kering tanpa lemak (BKTL), bahan pemanis, pengemulsi dan bahan penstabil. Penelitian ini bertujuan untuk mengetahui pengaruh penambahan ubi jalar terhadap sifat organoleptik es krim. Perlakuan yang dilakukan pada penelitian ini adalah perbandingan pemberian ubi jalar yang berbeda warna dengan formula sebagai berikut: B1=tanpa penambahan $(0 \%)$; B2=penambahan ubi jalar ungu 7,5\%; B3=penambahan ubi ungu 15\%; B4=penambahan ubi jalar ungu 22,5\%; B5=penambahan ubi jalar kuning $22,5 \%$; dan $\mathrm{B} 6=$ penambahan ubi jalar putih $22,5 \%$. Penelitian ini menggunakan rancangan acak lengkap yang dinilai oleh 22 orang panelis semi terlatih sebagai ulangan. Hasil penelitian ini menunjukan bahwa pemberian ubi jalar berpengaruh terhadap sifat organoleptik berupa warna, aroma, rasa, dan tekstur yang bervariasi. Tekstur paling lembut ditemukan pada produk tanpa campuran ubi ungu (B1). Tekstur dengan campuran ubi jalar paling baik yaitu lembut dan sedikit berserat ditemukan pada ubi jalar ungu campuran ubi jalar yang rendah dengan formulasi $7.5 \%$ (B2) dan $15 \%$ (B3)..
\end{abstract}

Kata kunci: es krim, sifat organoleptik, ubi jalar 


\section{Pendahuluan}

Tanaman ubi jalar (Ipomea batatas) merupakan tanaman yang berasal dari Amerika bagian Tengah. Sekitar tahun 1960-an tanaman ubi jalar telah menyebar hampir di seluruh wilayah Indonesia (Rukmana, H. R, 2001). Ubi jalar juga dapat tumbuh baik di dataran rendah maupun pegunungan. Di tiap daerah di Indonesia, tanaman ubi memiliki varietas lokal yang berbeda-beda serta warna yang berbeda. Selain itu ubi jalar juga memiliki keunggulan tertentu seperti contoh Ubi Madu Cilembu yang istimewa karena ketika dipanggang mengeluarkan cairan kental dengan rasa yang sangat manis.

Potensi besar ubi jalar terutama terletak pada kandungan karbohidrat, dimana sebanyak $75-90 \%$ berat kering umbi merupakan gabungan dari pati, gula, dan serat seperti selulosa, hemiselulosa, dan pektin (Hartoyo, T, 2004). Potensi lainnya dari ubi jalar adalah adanya pigmen antosianin sebagai pewarna alami yang menghasilkan penampilan menarik pada produk olahan. Selain itu antosianin juga berfungsi sebagai antioksidan yang diketahui dapat menetralisir radikal bebas penyebab penuaan dini dan pemicu aneka penyakit degeneratif seperti kanker. Ubi jalar merah mengandung beta karoten sebagai sumber vitamin A, dan serat sebagai sumber prebiotik untuk makanan BAL (Bakteri Asam Laktat) sehingga dapat dikembangkan sebagai pangan fungsional (Nuraida, dkk, 2004).

Es krim merupakan produk olahan pangan beku yang biasa dikonsumsi sebagai makanan selingan (dessert) dengan bahan utama dalam pembuatannya seperti lemak, bahan kering tanpa lemak (BKTL), bahan pemanis, pengemulsi dan bahan penstabil. Lemak susu (krim) merupakan sumber lemak yang paling baik untuk mendapatkan es krim berkualitas baik. Lemak susu berfungsi untuk meningkatkan nilai gizi es krim, menambah citarasa, menghasilkan karakteristik tekstur yang lembut, membantu memberikan bentuk dan kepadatan, serta memberikan sifat meleleh yang baik. Bahan kering tanpa lemak (BKTL) berfungsi untuk meningkatkan kandungan padatan di dalam es krim sehingga lebih kental. BKTL juga penting sebagai sumber protein sehingga dapat meningkatkan nilai nutrisi es krim.

Unsur protein dalam pembuatan es krim berfungsi untuk menstabilkan emulsi lemak setelah proses homogenisasi, menambah citarasa, membantu pembuihan, meningkatkan dan menstabilkan daya ikat air yang berpengaruh pada kekentalan dan tekstur es krim yang lembut; juga dapat meningkatkan nilai over run es krim. Sumber BKTL antara lain susu skim, susu kental manis, dan bubuk whey (Padaga, M, dkk, 2005). Bahan pemanis yang umum digunakan dalam pembuatan es krim adalah gula pasir (sukrosa) dan gula bit. Bahan pemanis selain berfungsi memberikan rasa manis, juga dapat meningkatkan citarasa, menurunkan titik beku yang dapat membentuk kristal-kristal es krim yang halus sehingga meningkatkan penerimaan dan kesukaan konsumen. Prinsip pembuatan es krim adalah membentuk rongga udara pada campuran bahan es krim atau Ice Cream Mix (ICM) sehingga diperoleh pengembangan volume yang membuat es krim menjadi lebih ringan, tidak terlalu padat, dan mempunyai tekstur yang lembut (Padaga, M, dkk, 2005).

Teknik olahan tradisional dari ubi jalar yang sudah banyak diterapkan di masyarakat dalam bentuk jajanan lokal, seperti kue apem, kue mangkok, dan pilus dari ubi jalar, termasuk juga keripik ubi jalar. Selain teknologi tradisional teknologi pengolahan pangan modern juga telah menghasilkan kreasi baru olahan ubi jalar, salah satunya adalah es krim 
ubi jalar. Oleh sebab itu, penelitian ini ingin mencoba untuk mengetahui pengaruh penambahan ubi. jalar terhadap sifat organoleptik es krim serta untuk mengetahui tingkat kesukaan panelis terhadap es krim ubi jalar.

\title{
2. Metode Penelitian
}

\subsection{Metode Penelitian}

Penelitian ini menggunakan Rancangan Acak Lengkap (RAL) (Steel and Torrie, 1995) yang dinilai oleh 22 orang panelis semi terlatih (Mahasiswa) sebagai ulangan.

\subsection{Materi Penelitian}

\section{Bahan}

Bahan yang digunakan dalam penelitian ini adalah : $6000 \mathrm{ml}$ susu full cream, 1200 gr susu skim, 1200 gr whippy cream, 42 gr agar-agar bubuk, 24 butir telur, 1200 gr dan 450 gr ubu jalar ungu, 225 gr ubu jalar kuning, dan 225 gr ubi jalar putih.

\begin{abstract}
Alat
Peralatan yang digunakan dalam penelitian antara lain : kompor gas, panci, sendok kayu, mangkuk tempat bahan, spatula, pisau, gunting, gelas plastik, gelas ukur, mixer, blender, timbangan, freezer, dan alat uji organoleptik yaitu kertas kuisioner dan alat tulis. Penilaian organoleptik dapat digunakan untuk menentukan kualitas dan membuat keputusan dalam mengkonsumsi es krim.
\end{abstract}

\section{Cara kerja}

Cara kerja penelitian ini dimulai dengan pembersihan ubi jalar ungu, ubi jalar kuning dan ubi jalar putih. Setelah itu dilakukan pengukusan selama 25 menit sampai ubi benarbenar empuk. Kemudian diamkan selama 5 menit, lalu pengupasan terhadap kulit dan dihaluskan dengan menggunakan sendok.

Setelah selesai perlakuam terhadap ubi selanjutnya yaitu pembuatan es krim dengan proses yang ditampilkan pada Gambar 1. Produk es krim dibagi menajdi 6 kategori yaitu:

a. $\quad \mathrm{B} 1=$ tanpa penambahan ubi jalar

b. $\quad$ B2 $=$ penambahan ubi jalar ungu 7,5\% tehadap $1000 \mathrm{ml}$ susu cair;

c. $\mathrm{B} 3=$ penambahan ubi jalar ungu $15 \%$ terhadap $1000 \mathrm{ml}$ susu cair,

d. B4= penambahan ubi jalar ungu 22,5\% terhadap $1000 \mathrm{ml}$ susu cair,

e. $\quad$ B5= penambahan ubi jalar kuning $22,5 \%$ terhadap $1000 \mathrm{ml}$ susu cair,

f. B6= penambahan ubi jalar putih $22,5 \%$ terhadap $1000 \mathrm{ml}$ susu cair. 


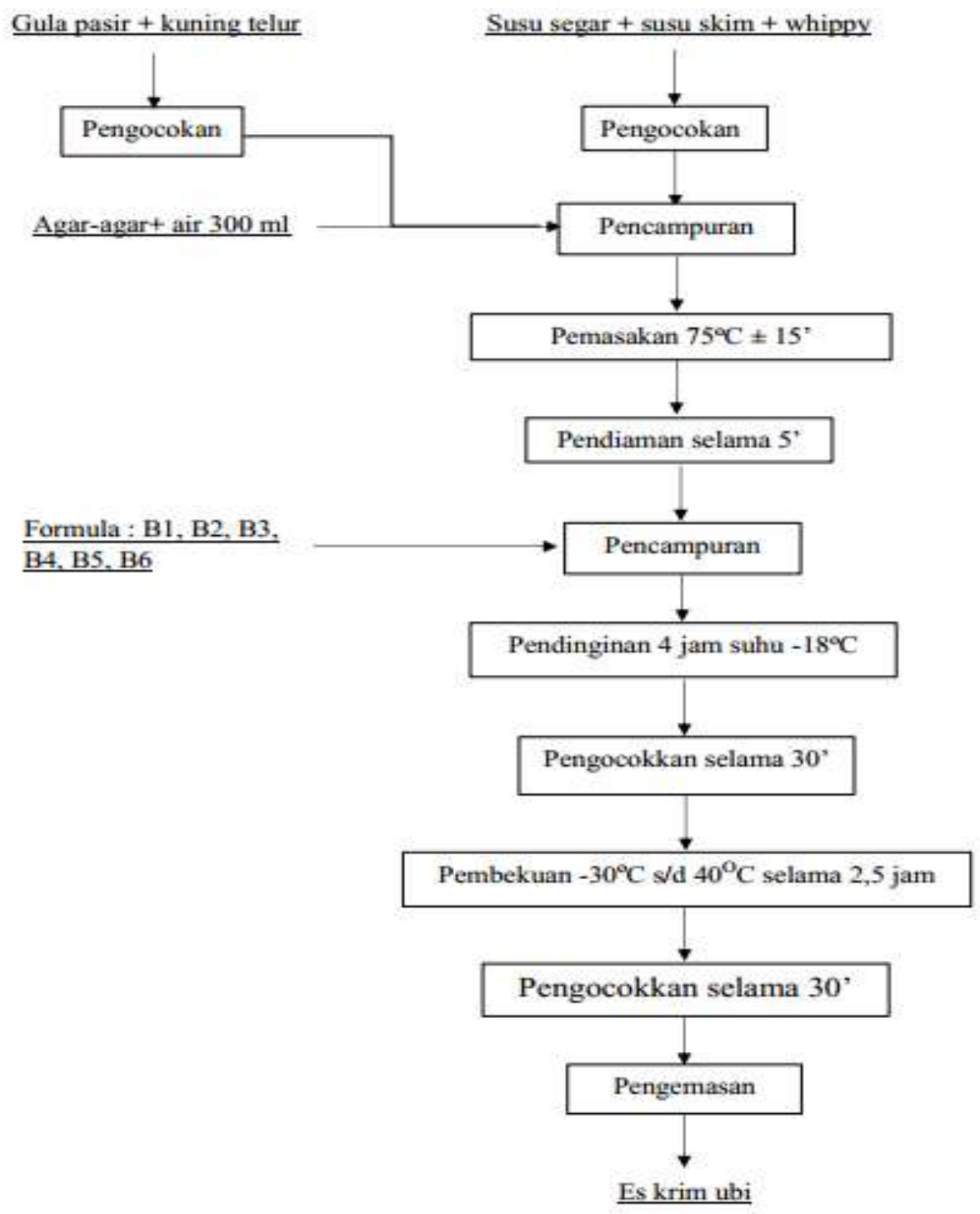

Gambar 1. Diagram Alir Proses Pembuatan Es Krim Ubi Jalar

\section{Hasil dan Pembahasan}

Menurut Padaga, M, dkk (2005), pada dasarnya kualitas es krim ditentukan oleh tekstur, rasa, bau, overrun, dan kecepatan meleleh. Tabel 1. Merupakan hasil uji organoleptik es krim ubi jalar yang dilakukan oleh panelis semi terlatih pada tanggal 25 Maret 2019. Secara umum berdasarkan hasil analisis organoleptik, es krim dengan perlakuan penambahan ubi jalar sebesar 0\% (B1), ubi jalar ungu 7.5\% (B2), ubi jalar ungu 15\% (B3), ubi jalar ungu 22.5\% (B4), ubi jalar kuning $22.5 \%$ (B5), ubi jalar putih $22.5 \%$ (B6) terlihat sekali perbedaan baik dari segi warna, rasa, aroma dan tekstur. 
Tabel 1. Hasil uji organoleptik terhadap es krim ubi jalar

\begin{tabular}{|c|c|c|c|c|}
\hline Formula & Warna & Aroma & Rasa & Tekstur \\
\hline B1 & Putih cerah & Cream susu & Terlalu manis & Lembut \\
\hline B2 & $\begin{array}{c}\text { Sedikit } \\
\text { ungu }\end{array}$ & Cream susu & Kurang manis & $\begin{array}{c}\text { Lembut sedikit } \\
\text { berserat }\end{array}$ \\
\hline B3 & Ungu & $\begin{array}{c}\text { Sedikit bau pati } \\
\text { ubi }\end{array}$ & Kurang manis & $\begin{array}{c}\text { Lembut sedikit } \\
\text { berserat }\end{array}$ \\
\hline B4 & Ungu cerah & $\begin{array}{l}\text { Aroma pati } \\
\text { sangat kuat }\end{array}$ & Kurang manis & Berserat \\
\hline B5 & $\begin{array}{l}\text { Kuning } \\
\text { kecoklatan }\end{array}$ & $\begin{array}{l}\text { Aroma pati } \\
\text { sangat kuat }\end{array}$ & $\begin{array}{l}\text { Tidak terlalu } \\
\text { manis }\end{array}$ & Berserat kuat \\
\hline B6 & Putih tulang & $\begin{array}{c}\text { Cream bukan } \\
\text { susu }\end{array}$ & $\begin{array}{c}\text { Vanilla cukup } \\
\text { kuat }\end{array}$ & Berserat \\
\hline
\end{tabular}

Penilaian organoleptik panelis untuk atribut warna es krim bervariasi. Warna ubi jalar yang kuning-orange memang berpengaruh pada warna produk es krim, dimana semakin banyak konsentrasi penggunaan ubi jalar, warna es krim akan semakin kekuningan dan tampaknya hal ini kurang diminati oleh panelis. Berbeda dengan ubi jalar warna ungu semakin banyak konsentrasi yang diberikan tingkat kesukaan nya semakin banyak. Hal itu disebabkaan warna ungu lebih menarik perhatian dari para panelis hanya saja dari segi pemanis perlu adanya penambahan konsentrasi. Sebagaimana warna es krim yang tidak dilakukan penambahan ubi. Warna putih alami dari susu juga sangat diminati oleh panelis.

Menurut Padaga, M, dkk (2005), rasa sangat mempengaruhi kesukaan konsumen terhadap es krim, bahkan dapat dikatakan merupakan faktor penentu utama. Saat ini, rasa es krim di pasaran sudah sangat beragam sehingga diperlukan kreativitas dan inovatif dalam memadupadankan rasa yang menjadi kegemaran konsumen. Rasa es krim juga dipengaruhi oleh beberapa hal seperti bahan pengental yang dapat mengurangi rasa manis gula dan perubahan tekstur yang dapat mengubah cita rasa es krim. Pada es krim ubi jalar rasa dipengaruhi oleh banyak sedikitnya penambahan ubi. Semakin banyak ubi ditambahkan maka rasa manis terhadap es krim tersebut hilang. Selain itu rasa dari susunya pun berkurang.

Rasa dan aroma merupakan salah satu komponen yang penting dalam penilaian konsumen terhadap suatu produk. rasa dan aroma es krim merupakan satu kesatuan yang saling menunjang karena hal pertama yang akan diperhatikan oleh konsumen saat membeli es krim adalah rasa dan aromanya Data hasil pengamatan untuk sifat organoleptik es krim dengan penambahan ubi jalar ungu terhadap aroma es krim, dapat dilihat pada Tabel 1.

Tekstur es krim dipengaruhi oleh ukuran dari kristal es, globula lemak, gelembung udara, dan Kristal laktosa (Suprayitno, E, dkk, 2001). Menurut Arbuckle (1986) tekstur es krim yang ideal adalah tekstur yang sangat halus dan ukuran partikel padatnya sangat kecil, sehingga tidak terdeteksi didalam mulut. Sedangkan tekstur yang buruk adalah greasy (terasa ada gumpalan lemak), grainy (terasa seperti tepung), flaky/snowy (terasa ada serpihan es), lumpy/gelatin (seperti jelly), dan sandy (berpasir) (Suprayitno, E, dkk, 2001). Pada tabel 1 menunjukkan hasil nyata perbedaan tekstur es krim antar formula. Es krim yang ditambah dengan ubi cenderung memiliki serat dan terdeteksi oleh mulut. 


\section{Kesimpulan}

Dari keenam formula yang dilakukan dapat ditarik kesimpulan bahwa penambahan ubi jalar dengan varian formula dan warna yang berbeda sangat berpengaruh terhadap sifat organoleptik es krim. Baik dari segi warna, rasa, aroma, dan tekstur. Tekstur es krim yang ideal adalah tekstur yang sangat halus dan ukuran partikel padatnya sangat kecil. Tekstur paling lembut ditemukan pada produk tanpa campuran ubi ungu (B1). Tekstur dengan campuran ubi jalar paling baik yaitu lembut dan sedikit berserat ditemukan pada ubi jalar ungu campuran ubi jalar yang rendah dengan formulasi $7.5 \%$ (B2) dan 15\% (B3).

\section{Pustaka}

Arbuckle, W.S. 1986. Ice Cream. Avi Publishing Company. Inc. London Hartoyo, T. 2004. Olahan dari Ubi Jalar. Trubus Agrisarana. Surabaya.

Nuraida, L., Palupi, N. S., Anggiarni, A. N. dan Pertiwi W. 2004. Pemanfaatan Ubi Jalar sebagai Prebiotik dan Formulasi Sinbiotik sebagai Suplemen Pangan. di dalam Nuraida, L., Hana, Sri, R. D., dan Didah N., F. 2008. Pengujian Prebiotik dan Sinbiotik Produk Olahan Ubi Jalar Secara In Vivo. J. Teknol. dan Industri Pangan, Vol. (19) : 89-96.

Padaga, M dan M, E, Sawitri. 2005. Es Krim yang Sehat, Trubus Agrisarana. Surabaya.

Rukmana, H, R. 2001. Aneka Keripik Umbi. Kanisisius: Yogyakarta.

Steed, L. E dan V. D. Truong. 2008. Anthocyanin Content, Antioxidany Activity, And Selected Physical Properties of Flowable Purple Fleshed Sweet Potato Purees. Journal of Food Science. 73:215-225

Suprayitno, E, H, Kartikaningsih, dan S, Rahayu, 2001, Pembuatan Es Krim dengan Menggunakan Stabilisator Natrium Alginat dari Sargassum sp. Jurnal Makanan Tradisional Indonesia. Vol, 1 No, 3, Hal, 23-27. 